\title{
Creativity \& Innovation: Four Key Issues from a Literature Review
}

\author{
Francesco Pisanu $^{1}$, Paola Menapace ${ }^{2}$ \\ ${ }^{1}$ Provincial Institute of Educational Research and Experimentation (IPRASE), Trentino, Italy \\ ${ }^{2}$ Bielefeld Graduate School in History and Sociology (BGHS), Bielefeld University, Bielefeld, Germany \\ Email: francesco.pisanu@iprase.tn.it, paola.menapace@uni-bielefeld.de
}

Received January $7^{\text {th }}, 2014$; revised February $7^{\text {th }}, 2014$; accepted February $14^{\text {th }}, 2014$

\begin{abstract}
Copyright (C 2014 Francesco Pisanu, Paola Menapace. This is an open access article distributed under the Creative Commons Attribution License, which permits unrestricted use, distribution, and reproduction in any medium, provided the original work is properly cited. In accordance of the Creative Commons Attribution License all Copyrights (C) 2014 are reserved for SCIRP and the owner of the intellectual property Francesco Pisanu, Paola Menapace. All Copyright @ 2014 are guarded by law and by SCIRP as a guardian.
\end{abstract}

\begin{abstract}
This paper is about creativity and innovation in the educational field. Through a literature review, we describe the results of two decades of research on creativity and innovation in the educational and organizational field, to underline what seemed to work and what did not, to enable these processes function effectively. In this literature review, a search of publications dealing with the issues of innovation and creativity and the links between these two issues has been made. We decided to put these studies in four theoretical, ex-post created, dimensions: organizational structures, individual characteristics, training methods and pedagogical practices and training content. The content of this article is based on one of the outputs of the European Commission funded project, named CLEAR (Creativity and innovation: pedagogical framework for the learning chain).
\end{abstract}

Keywords: Creativity; Innovation; Training; Organization; ICT’s

\section{Introduction}

This paper is about creativity and innovation in the educational field. For "educational field", we mean not only the instructional level, but also the organizational one. The content of this article is shaped primarily for this target audience, that is educational institutions and people who work in them, and for educational researchers studying them. What we present here can be traced back to the key elements of creativity and innovation that intersect different levels in an educational institution functioning. We will consider micro-level interactions among individuals; that is teachers with their students; mid-level interactions within groups of teachers inside these organizations; and a macro-level focus looking at the educational institution from a more comprehensive way, such as the organizational structures and dynamics that can support and enhance the levels of creativity and innovation.

As pointed out by Bocconi et al. (2012), there is a reciprocal relationship between innovation and education. Educational institutions, from primary to higher education, are optimal environments for enabling experiences of innovation that learners can transfer to real-life settings (Schwartz, Varma, \& Martin, 2008). According to OECD/CERI (2010: p. 14), educational innovation is "[...] any dynamic change intended to add value to the educational process and resulting in measurable outcomes, in terms of stakeholders satisfaction or educational performance". We mean the term "stakeholders" in this definition in a wider sense, considering, as already stated, different actors, from students to teachers to principals/managers and so on. A definition of innovation from West and Rickards (1999) would be more appropriate for our work: "[...] the intentional introduction and application within a job, work team, or organization of ideas, processes, products, or procedures that are new to that role, work team, or organization and that are designed to benefit the job, work team, or organization” (p. 45).

Through this literature review, we tried to draw, in a variety of subject matters, the results of two decades of research on creativity and innovation, mainly in the educational field, to be able to say today, not in a definitive way, what seemed to work and what did not, to enable these processes function effectively. We have found already known issues related to these topics, but also unexpected ones. For example, some processes that are expected to be intrinsically linked to creativity, such as team working, do not always mean a direct support to creativity and development of innovation. If we believe that creativity and innovation can be decisive and essential for educational institutions, we can not only make sure they occur regardless of what people think or what they might do to manage the process. It is necessary for those who lead these organizations to take responsibility in creating scenarios, supporting people and driving innovation to destinations that are aware, clear, not only believing that creativity is free and open. From this point of view, creativity and innovation may not work by their self, or they may not be effective.

Creativity and innovation have been, therefore, considered together, with innovation as a process, the result of a creative idea (West \& Farr, 1990). In this view, the original idea can be seen as an individual factor, then actualized in an innovation, which can also be social. Innovation can arise from the process in which the creation of the idea must be continuously rede- 
fined in group with other people, leading to a negotiation in which there is a process of implementation of this idea, and finally a result and a product. At the end of this process, it cannot be said that it is a process strictly individual, this is a social process, then there is a part of the generation of the idea that starts originally from an individual cognition, which then can be shared within the group, by single member working with other people. Innovation, at the end, becomes a social practice.

In the present literature review, a search for publications dealing with the issues of innovation and creativity, and the links between these two features, has been made. It is over known that the literature on creativity and innovation is something like endless and includes many areas, ranging from to say, psychology, sociology and economics. It is probably one of the most studied topic of the last twenty years.

Journal articles dealing with the themes of innovation and creativity have been examined. We decided to put these items in four theoretical, ex-post created, dimensions.

First, we introduce the organizational structures, and especially all the aspects related to the topic of leadership in organizations, group work in organizations, team work and also innovation in educational institutions or in other organizational contexts. Second, we will talk about individual features. Researchers talk about them in terms of personal characteristics, so, in short, it is assumed that there are individual characteristics that affect creativity and innovation through the literature that deals with the issue of personal characteristics. There are features that can be encouraged or at least be taught or learned in their own contexts: motivation, aptitudes, interests, skills, and knowledge. Many of these features are not already present, but develop in a context. The third dimension is pedagogical practices. Essentially this is what we put in place in order to foster creativity and innovation in the different contexts, that is in the educational institution, but also in other organizational contexts, private or public. Practices differ considering the training material that is what it used to be taught to foster creativity and innovation in different contexts. This is the fourth dimension considered.

The content of this article is based on one of the outputs of a European Commission funded project, named CLEAR (Creativity and innovation: pedagogical framework for the LEARning chain). The project aims to improve lifelong learning strategies, by creating a pedagogical framework so as to raise awareness on the importance of creativity to empower individuals and to transfer and develop innovation in organisations. The project partners (from Italy, UK, Belgium, Spain and Norway) have analyzed policies and approaches to develop creativity in five different European countries and collected good practices realized in three sectors of the learning chain: scientific and technology academic education, post academic/executive/non academic higher education, continuous training, with the aim to share and transfer them from the learning settings to real life environments (Salampasis, 2013). This article is based on a literature review on this topic we did in the project as the local unit.

The article is organized as follow: A first main part on the key dimensions we underlined to summaries all the literature we analyzed; a brief second part for final discussion and conclusion.

\section{The First Dimension: Organizational Structures}

About the first group, the organizational structures, we have restricted the literature review on leadership for creativity and innovation (Andrews \& Farris, 1967; Barnowe, 1975; Weick, 1995; Mumford, Scott, Gaddis, \& Strange, 2002; VinarskiPeretz \& Carmeli, 2011; Mumford \& Gibson, 2011), which contains the crucial issue of mentoring. There are technologies that can facilitate the meeting, in a company, among people who are already leaders, with people whom to gain their leadership skills. This is done through mentoring, for example, a technique to support the person who is preparing to acquire leadership skills, and needs the support of a mentor.

There are technology-based tools for developing creative/ innovative leadership capacity (Antes \& Schuelke, 2011). An important point in the literature is the need for those mentored to reflect and capitalize on experiential, case-base knowledge offered by the mentors. The technology-based tools used regarding this need are simulations, e-mentoring, multisource feedback, social media and succession planning programs. An interesting article regarding leadership has been released by McEntire and Greene-Shortridge (2011). This is about the recruiting process of innovative candidates into an organization. The article presents some approaches and good practises to select candidates with innovation potential. There are, for example, some recruiting strategies based on behavioural assessment, behavioural based interviews and innovation-targeted succession planning. The main point stressed here is the use of two relevant resources such as a professional network and panel interviews for the selection. The questions to be yet answered by the authors are: how should the announcements be structured the job description? Should technical fundamentals or other skills be emphasized? How and who should conduct the interview?

We have also focused our attention on teamwork. About this topic, we first must report in more detail about the literature on leadership in innovation. We have focused primarily on the work of Mumford and Gibson (2011). This work underlines influences that can be both direct and indirect inside the organizational contexts, i.e. the leader can affect creativity and innovation in his working environment in a direct and indirect way (Hunter \& Cusherbery, 2011). What are the leader's direct influences? His personal characteristics, i.e. his skills, his intention to get involved and to support teamwork. There are also direct and indirect influences on the responsibility in leading work teams. These may be, for example, the ability of the leader to make resources available, (even financial resources), to inspire and motivate the workers to be more creative and to guide them into action in the innovation process. Leaders can have an impact in setting up an appropriate climate, giving to the employees different levels of autonomy, freedom and recognition.

Among the indirect influences, which a leader may have, there is that of role modelling (Bandura, 1977). Leaders are influential if they undertake risks and unconventional behaviours they make for other employees those behaviours acceptable. An important factor has been also recognised to be the leader capacity to build up the team, deciding which individuals to choose and how many individuals to choose. The leaders have to find a good team-size, including individuals which present different skills, which can be applied in different times of the innovation process.

The key point in this theme is (mostly in the context of education) to see what could be the incentives to be given to teachers. Not money based incentive, but the incentives that princi- 
pals, or people who have leading duties inside this organization, they could give to their teachers, who seek to participate in innovative projects. In this context, there are, therefore, direct influences in the creative process during the generation of ideas. Among these, there is the leader's ability to establish a vision, and to provide guidance to found and set resources, showing specific technical expertise in different fields. A crucial aspect in Hunter and Cusherbery's (2011) work is that the leader has a different role in different phases of innovation from idea generation to implementation of the idea.

In the initial phase of the process, the leader has to support the idea and also to determine a proper climate so that there is a negotiation among the people of his team to work on the generation of ideas. In a second step, the leader must try to manage the entire organizational process to bring innovation. The leader must, therefore, share this process with other actors. He needs to meet the external environment and faces with a whole set of issues that have nothing to do with creativity, but with the managing of resources and group climate. The leader has to be supportive in generating ideas, and in the evaluation of it at the end of the process.

So at different levels of innovative phase, the leader has a different leadership habit. Some questions about these issues might be: how effectively is it possible to train these people? How is it possible to train them to have leadership both creative and innovative? The kind of leadership that may be suitable for the phase of idea generation, but also at later stages of implementation of the idea. From this point of view, some leader's different skills are needed.

With regard to team innovation, among other works, we have considered the work of Hoegl and Parboteeah (2007), on creativity in innovative projects, on how important collaboration and teamwork is based on massive tradition on research on this topic (Amabile, 1983; 1996; Watson et al., 1991; Diehl \& Stroebe, 1991; Tannenbaum et al., 1992; Weick \& Roberts, 1993; Ford, 1996; Ruscio et al., 1998; Madhavan \& Grover, 1998; Sicotte \& Langley, 2000; Schulz et al., 2000; Hoegl \& Gemuenden, 2001; Taggar, 2002; Okhuysen \& Eisenhardt, 2002; Thompson, 2003). This is a very interesting work, in which it was verified that the group work tremendously facilitates the development of technical skills, but, at the same time; he can be a barrier in the implementation phase and for the application of divergent thinking techniques.

This is because creativity also needs a significant level of conflict and confrontation. In a team, there are group cohesion, social cohesion, leading to diversity. The members are more interested in having gratification or otherwise be recognized by the other members of the group, rather than bringing different ideas to implement a more divergent one from what others think. The quality of group work is influenced by these two dynamics. If there are conflicts in work teams at the right times, these can be useful to support and trigger creativity and innovation. The research of Hoegl and Parboteeah (2007) was conducted in Germany, with 145 specialists in software development in four different laboratories. In this case, the construct of team innovation has been analyzed. The quality of the team work (Hoegl \& Gemuenden, 2001) is based on these six elements: communication, coordination, balance of the contributions of team members, mutual support, effort and cohesion. In this article, it was found that these group characteristics facilitate the implementation of technical skills, but they may, in fact, to stop more creative and divergent thinking. This is a form of barrier to the emergence of divergent thinking and new ideas within the group. If there is a lot of social cohesion, people are looking for more approval and agreement, rather than creativity or innovation. This is the paradox of the groups members who live and work for a long time together. For example, this aspect is very well studied in the network analysis: when the groups are very cohesive it is difficult to lead them to openness outwards. This feature has been studied by Granovetter (1973) in his famous study of weak-ties. It is also crucial to have weak ties, and even be able to open up to other connections, to other realities, not being fossilized and not staying within their own context.

This feature has been also studied, for example, by Odoardi, (2008) in the educational context. He has conducted research in a school district of Florence in Italy, with 93 teachers, and he underlined the different stages of generation of an innovative idea in these organizations. In the first stage, the variable that counts a lot is the interpersonal conflict that could happen inside groups of teachers, and that is not seen, in this work, as something completely negative. In the second phase, the teacher needs organizational support: they can have an idea and want to implement it, but they need the support of their principal and their colleagues in the implementation of the idea. In the initial phase, then, a kind of conflict may assist in the generation of ideas. Being more open also help to capture stimuli from the other, whereas in a second step collaboration is critical. At the beginning of the creative process inside the group, it is better stimulate diversity, whereas, at a later stage, it is good to have collaboration and openness to encourage the innovation process. Another work by Hoegl and Parboteeah (2006) investigated the role of reflexivity in innovation projects. They argue that reflexivity is associated with a better team performance. In this study team reflexivity was defined as a set of behaviours: "It includes behaviours such as questioning, planning, exploratory learning, analysis, making explicit use of knowledge, learning at a meta level, and reviewing past events with selfawareness.” (West, 2000: p. 559). This aspect of reflexivity has also been further studied by Hammedi, van Riel and Sasovova (2011). They explore decision-making effectiveness during the preliminary phase of the screening of ideas. This process is influenced by the presence of a transformational leadership and different cognitive styles. This study added further relevance to the thesis that in the early phase of the innovation project (selection of creative ideas), under high levels of uncertainty and ambiguity, the team leaders should be opened to confrontation, argument-based discussion, rather than rigid evaluation criteria and inflexible methods. The reflexivity, as conceived by West (2000), has been here considered enforcing this argument.

\section{The Second Dimension: Individual Characteristics}

About individual characteristics, we have considered primarily the innovative behaviour of the entrepreneur that seems to encapsulate the features needed to create a new business, and also to identify new opportunities (Schumpeter, 1942; Maslow, 1954; Gibb, 1985; Bygrave, 1994; Van Vuuren, 1997; Kuratko \& Hodgetts, 1998; Sternberg \& Lubart, 1999; Rae \& Carswell, 2000; Flynn et al., 2003, Antonites, 2003; Zhao, 2005). Rather than focusing on only a vision centred on individual features, we have decided to explore the features of the context associated with them. A necessary clarification is that entrepreneur- 
ship, or entrepreneurial attitude, is not necessarily linked to a person who plays a real entrepreneurial role, but it is more a kind of individual characteristic, useful to stand and face the external reality. We emphasize, in this way, some features that we can find in successful entrepreneurs. This allows to understand what are the features that people can apply much more effectively while interacting with the outside world. Having an entrepreneurial approach means to be self-assertive, mastering all the tools to know the local context, make decisions, etc.

In our review, we went to study a series of articles. The first of these articles deals with the results of the TRACTORS project (2007) by Sarri, Bakourus and Petridou (2010). This article emphasizes how valuable is training for creativity and innovation for entrepreneurs in three regions of the Northern Greece. The authors have tried to investigate (in a similar way as mentioned above) the attitudes, perceptions, behaviours that entrepreneurs have towards creativity and innovation, in order to understand the attitude that entrepreneurs have. This aspect is hugely important not doing the mistake of seeing the entrepreneur as a simplified category. there are many differences, characteristics, experiences that explain how entrepreneurs set against creativity and innovation in their companies. Among others, in some European countries organizations, also in schools, in secondary schools mainly, there are curricula of entrepreneurship or entrepreneurship education, following the way underlined previously. That is not related to what are the features the best entrepreneur should have, but what may be the skills which enable a person, once he or she get adult, to face better his or her own professional and working life.

In this study that was carried out in three different regions of Greece; creativity and innovation have been found to be positively related, for the entrepreneurs interviewed. It has been seen that, in their view, creativity and innovation help a company to develop, so it is extremely important to have a specific training on creativity and innovation. Essential elements that emerged in this study are, therefore, the importance of perceptions and attitudes and motivation, awareness of the value of innovation by the entrepreneur, the importance of having specific training on creativity and innovation. From this point of view, there is no need to have a general training, but this must be very specific. The results of this study were then used to develop training strategies that might be suitable for these entrepreneurs. Then try to design a program fitting their needs, starting from their needs. They recognized the need for the training and specific tools both for them and their peers. Finally, they identify a series of barriers, as the lack of financial resources and the transfer design of creativity and innovation training for their work. The article by Smith and Beasley (2011) investigated the main barriers that influence young graduates to start up their own business in the field of the creative and digital industry. The dimensions which were considered in this study were gender, age, ethnicity, entrepreneurial background, and emerging perceptions of career aspirations. After the questionnaire, the respondents (7 graduates) were asked to take part in follow-up interviews which investigated the main constraints/enablers during the start-up, their future plans and the improvement of business support opportunities. The results of this study were the following: lack of general business knowledge, contradictory advisory support from external agencies, lack of sectors specific mentors, lack of funding devices and experiences of familial entrepreneurship. The perceived enabling factors were the following: co-mentoring from business partners, course content, financial gain, creative and innovative ideas, control and risk-taking, support from the university.

Another work in this area is focused on the creative behaviour (Heinonen, Hytti, \& Stenholm, 2011). Several strategies for the search of opportunities may be an active search, the acquisition of knowledge, the innovative behaviour and collective action (Miller, 1987; Kirzner, 1999; Puhakka, 2002, 2007; Ardichvili et al., 2003; Companys \& McMullen, 2007; Tang \& Khan, 2007; Heinonen et al., 2010). For creative behaviour we mean the ability to search information in a creative way, and then to start a wide set of communication channels, of creative modes to recognize the opportunities inside the environment and, therefore, also take them off.

This study emphasizes that the creativity per se is not directly associated with the feasibility of a business idea. That is, it is not enough to be creative to be able to put into practice a business idea. However, creativity is enhanced by the use of the creative strategies, the research opportunities, and also the use of a variety of analytic behaviours to find information, which may be knowledge that can be used for the feasibility of a business idea.

The fascinating thing is that this study has investigated two main aspects of entrepreneurship. The more innovative and creative aspect is that entrepreneurship facilitates the implementation of the business idea, and it seems to be more linked to specific skills and knowledge. These are two aspects of entrepreneurship that can not be separated. There is the creative side, but also the development of knowledge, precisely the aspect of the information it is possible to gather, that is more systematic and less creative.

One of the two aspects alone may not be enough. So if we want to be "artists", just to resume this metaphor, in the sense of generating ideas, that might not be enough, we must also have an infrastructure at the level of individual characteristics. This is the ability to find information and also to be able to compete with the environment, and inside the organization. Clearly, this is not enough to be creative to take on a business idea. The results of this research indicate that creative individuals adopt a variety of behaviours to carry out the feasibility of their business idea. There are several ideas that are really creative and innovative, and individuals believe that these ideas really are, focusing primarily on creativity as an added value. As we said before, creativity is also connected to handle more analytical processing, based on more detailed information gathering, on knowledge of the business and core markets

\section{The Third Dimension: Training Methods and Pedagogical Practices}

This is the level of teaching and instructional methods. In the review, we have focused on creative problem solving. We have also tried to see what might be the practices that can be implemented at the level of European union. We decided to review the article by Sahlberg and Oldroyd (2010). These authors state that there is a discrepancy in the current directives of the EU, the Lisbon Strategy and educational policies in European countries. In their view, there is a prevalent focus on the standardization of students academic results, and thus the comparability of these results. From their point of view to encourage creativity and innovation, it is better to take another way, or at least not just the way of learning standardization. There is a need to try to find a way to combine both the need for comparable systems, but also with global sustainability (Brundtland, 1987; Bils 
\& Klenow, 2000; Rees, 2003; Steffen et al., 2007; Glaeser et al., 2004; Porter et al., 2004, 2008; Meadows et al., 2004; UNESCO, 2005; Doppelt, 2008;). These should not be two divergent roads anymore, they need to be integrated inside local and national educational policies.

The authors propose to focus primarily on a new concept of knowledge creation. It must be taken into consideration that there are more different ways to create knowledge inside and outside the educational settings. There are more situations, and there are several processes related to knowledge creation. Innovation, however, must always be seen as something that adds some sort of comfort to our lives for our society. At the same time, it is also crucial to continue to have a structured look at the achievement data. The author does not want to mystify the logic of the OECD PISA-like studies, or at least the logic of data benchmarking, only trying to find a way to combine these two instances. That is, the need to have an educational system where there might be the possibility of having creativity and innovation, but also the need to compare different educational systems among them. There is a need, therefore, to enhance the social capital, seeing that the greatest innovations happen always in contexts where there are group and community level collaborations, where there are partnerships, and where people just have this ability to forge connections with each other and the external environment. Sahlberg and Oldroyd (2010) focus primarily on these dimensions and what they essentially say is that a wide range of pedagogical practices already exists in the educational literature.

The authors present in this article five practices which can be combined with the need to develop creative skills both for future competitiveness and sustainable development. First, the cooperative learning, that can be applied, through the logic of competitiveness and sustainability, just because it leads to this positive attitude towards others, to the possibility of a comparison between peers, and it can be useful to share importance resources that can be taken from others. Second, they identified the problem-based learning, to stimulate the ability to find creative solutions. Further practises are project-based learning, central conceptual structures and creative problem solving. The authors argued, there are many techniques that are already available which are already widely documented since the early 20s of the last century, so there is no need to invent something new. What is needed to do is find ways to practice these techniques within educational and training institutions in a better and more effective way, considering the issue of the learning transfer in teaching these methods to teachers. Clearly if, as we said before if a teacher is interested in applying these techniques in the context of the school, but if not in front of a supportive environment that supports this, the pedagogical practices can be good, but if there are no support then the practical tools becomes much more difficult to be implemented.

Regarding to the policy about how entrepreneurship should be implemented in formal education one example has been shown in the study by Eickhoff (2008) on the plan of the leading trade and industry organizations in Germany, aimed to develop entrepreneurial thinking and actions in secondary education. The main goal of this plan was to assure that the students could acquire the entrepreneurial competences at all stages of the formal educational system. This plan (named Entrepreneurship Education Plan) was designed as a curriculum, covering all instructional issues, such as the target group, the goals, the content, the methods and the monitoring/evaluation of the teaching/learning outcomes. The logic should be to increase the competences acquired at each level of the educational system. The main objectives of the plan were to include entrepreneurship into the national curricula as in other European countries and to provide support to schools and teachers. As written before this plan should be based on the acquisition of different measures for each stage of education. Pupils from primary to secondary education should familiarize themselves with entrepreneurship in a positive manner. The main actions proposed by the plan regarding this objective at the level of curriculum were to insert a general knowledge of enterprises' functions and their contribution to society and to recognize entrepreneurship as an economic, competitive factor and as an opportunity for the reintegration of unemployed in the world of work. The measures recommended in this work (Eickhoff, 2008) to implement these actions are to allow better training for teachers working on team-teaching concepts, in which teachers and enterprises design the teaching content and the need for the teachers to be provided with curricular recommendation, plans and topic-based media. For vocational training students, entrepreneurship should be taught as an entrepreneurial attitude to the work, which is usually required to entrepreneurs but in the future even more to employees also. This should lead to employability and to open up new career possibilities in self-employment, reducing youth unemployment. In order to foster these actions, young people should exercise their entrepreneurrial skills in training, planning games or students firm simulation activities. The methods to be applied should be: case studies, planning games, entrepreneurship training for teachers and enterprise trainers, the exchange of experiences between practitioners. For continuing vocational training and higher education, the plan suggests that entrepreneurship can be integrated into existing topics. Some proposed measures are manager training or lecture based seminars, seminars on how setting up a business, and further guidance and coaching. Creative teaching methods, therefore, have to be more practice-based. Another article by Gibson (2010) focuses on how creativity and innovation can be implemented at the university level, based on a wide literature about creativity pedagogy (Koestler, 1964; Boden, 1990; Bourner \& Flowers, 1997; Robinson, 2000; Florida, 2002, 2005; Sternberg, 2006; Haring-Smith, 2006) and to the literature about creative teaching (Amabile, 1983; Boomer, 1992; Bereiter, 2002; Cutler, 2003; Sawyer, 2004; Grainger, Barnes, \& Scoffham, 2004; Simon \& Hicks, 2006; Cornish, 2007). The author asks if university-level creativity and innovation should be limited to students, or diffuse to academics. Gibson (2010) poses the question: where can be identified creativity and innovation within the university setting (Csikszentmihalyi, 1988)? The author describes a whole range of strategies to promote environmental and systemic creativity and innovation within the universities. It presents a student-centered pedagogy, to develop exactly creativity and creative techniques that require openness to experience, working in teams, taking risk, flexibility, spontaneity and openness. The ability to improvise is important also (Sawyer, 2004), because, in fact, doing creativity and innovation in educational contexts is to enter into contexts that are already organized. Giving a structure to this training intervention is to improve the ability to manage or to put it in a context already structured and organized processes. Though this study is from the academic field, many of these insights are fully appropriate also in other educational contexts that are not 
strictly academic. The great debate, for example, on teaching centered pedagogy vs. student centered one, which has not found a permanent solution to date, it can be connected directly to this topic. How much autonomy as do we want, as teachers, to give to students? How much coverage teachers have to maintain in teaching? The important thing is that there would be an active participation of students that the student would be placed in an environment able to improve their responsibilities and autonomy towards their learning.

Strictly related to these topics is the article by Gilbert (2012) which refers mainly to entrepreneurship and innovation education literature (Gibb, 1996; Cope \& Watts, 2000; Hannon, 2004; Pittaway \& Cope, 2005; Solomon, 2005; Smith et al., 2006; Rae, 2010). Many of these researchers pointed out "the tension between bureaucratic control methods to enterprise learning predicated upon standardized techniques that facilitate tangible and measurable outcomes" (Rae, 2010: p. 594), and more dynamic methods based on experiential learning that promote creativity and innovation. In this study, the author tries to identify critical elements of the learning process in order to manage and design collaborative industry-related training programs. The study outlined that skill and capability development of entrepreneurship students, their self-confidence and selfefficacy, support the development to rapid innovation prototyping rather than applying a traditional business plan approach. This study was conducted to test the application of a new education project (named Innovation Fast-track Program) in Australia, which was designed in collaboration with the local production sector considering three main dimensions: different stakeholders' point of view and the development of their expectations, the variability of students' experiences and the level of engagement of the university partners. In the next issue, it will be presented the main results from some studies about the training content, which should be delivered in order to foster creativity and innovation.

\section{The Fourth Dimension: Training Content}

The article by Gibson (2010) already mentioned in the previous section mainly focuses on the environment, that is on how the external environment should foster creativity and innovation of the students. According to the author, it is crucial to take the time, a lot of time, for creative thinking, to reward ideas, release thoughts and creative artefacts, and to encourage the taking in charge of risk and accepting errors. This is a very important aspect in the literature on this topic. It is very important, from teachers' point of view, not to have the attitude of inhibiting the student when they are making mistakes. Learning from mistakes is also a way to get the student thinking about how active is their learning process. Thinking from various perspectives, identify interests and problems, generate multiple hypotheses, thinking about the process of thinking, that is applying meta-cognition, then to reflect on their own learning process. Following Amabile (1998), Gibson (2010) argue that competition, restricted choices, confirming pressures, evaluation, frequent failures can destroy the potential for creativity and innovation.

Assessment is another tremendously important issue, because is impossible to talk about teaching practices and training content without integrating them in their evaluation practices. The author argues that, in the context of education, the evaluation should be seen as a moment that is already part of learning process, not just a device to verify if the students have learned or not, but considering it as a sort of an ongoing process alongside learning. Learning and assessment must be integrated, not separated. From this point of view, the key issue is the negotiation of the curriculum. In the process of evaluation, we need to discover how this negotiation can actually be done in large universities, such as the current ones. In this work, Gibson (2010) focuses on the ability to create groups of teachers who work exclusively on the tasks to be assigned for creativity and innovation. The author finds it necessary to look also for evaluation of students, that is a kind of peer evaluation, letting students, in pairs or groups, to assess independently their own progress.

About the issue of creativity and assessment, there is a new growing literature on how education is taught, delivered and assessed in the field of creative disciplines and entrepreneurship, mainly in the UK context (Rae \& Carswell, 2000; Gibb, 1996; Hannon, 2004; Matlay \& Carey, 2006; Penaluna \& Penaluna, 2009). In the study of Carey and Matlay (2010), the authors identify some characteristics of the creative education and assessment such as experiential environment, project-based learning, and peer reviews, which could be transferred to entrepreneurship education and business schools. They surveyed entrepreneurs coming from 13 sub-sectors of the creative industry which encompasses 13 different fields (DCMS, 2006). The main results from this study show that there are different creative styles and ideas to take in consideration when designing general enterprise education in business schools. The assessment is often characterized by formative, peer-enabled and discussion-based techniques. Students have to make a public presentation of their projects and the assessment process arises in the context of a critique. The study stresses the importance of the teachers' relationship to industry field, in order to have a real work perspective and to help students to contextualize their learning.

Another similar work is the one by Penaluna and Penaluna (2009). Based on the assumption of Gibb (1998) that there are no general codes about how to measure the degree of entrepreneurship, and on the suggestion from Rae (2007) in looking at the entrepreneurship as a kind of applied creativity, the authors seek to answer the question: how can creativity in entrepreneurial learning be assessed? Creativity is here conceived as idea generation, innovation and opportunity recognition together (Hamidi et al., 2008; Pittaway et al., 2009). These authors suggest applying the pedagogy from design and creative based subject matters to develop curriculum for entrepreneurship. About this point, in the UK a Quality Assurance Agency developed a benchmark statement (QAA, 2008). The authors argue that the need to have a focus in the pedagogy of the creative based subject matters and not only at business schools traditional techniques, has been required by the fact that the assessment approach from these disciplines can be easily applied to new and unpredictable scenarios, and because that in the field of assessing creativity art and design, educators already have had a significant experience. The authors consider the following principles as the main pillars in assessing creativity in entrepreneurship: experiential learning in a curiosity-led environment; application of different approaches to lead students to discovery based learning, and seeing problems as learning opportunities.

One example of a program which was delivered according to the Biosciences benchmark statements in the UK was reported 
in the study by Wakeford (2011). This article is about the evolution of an e-learning project in the bioscience. This article seems to be particularly interesting because the author offer a comparison between the results of traditional training program and an e-learning based course in which creative pedagogy of critical thinking, peer to peer assessment and student-lead inquiry are used. The structure of this program was based on the Community of Enquiry Model developed by Garrison, Anderson and Archer (2002). This model is a framework of collaborative and constructivist on-line learning experience which is defined by the interactions between the instructor, the students group and the academic context. In this e-learning course students were asked to evaluate a selection of on-line resources before to work in groups to generate new ideas. According to Wakeford (2011), the students had to use divergent thinking techniques such as brainstorming and brain-writing, use of random words and visual prompts to stimulate ideas with association, and the use of analogies to develop contextualization and to visualize ideas. The results of this study showed the existence of not significant difference between the two courses. Another important result, however, has been recognized to be the feasibility in the field of bioscience of such e-learning projects. Students also reported to be satisfied about this collaborative approach. They could freely choose these e-learning projects instead to follow a traditional laboratory project, although especially the laboratory experiments are considered to be very important in the field of bioscience.

Another work which goes in-depth in the study of the successful education techniques for creativity and innovation is the one by Birdi (2005). This work is about evaluation research on the long-term impact of three types of creativity training workshops conducted within an organization (business beyond the box, lateral thinking, and De Bono course). These three workshops were offered to 71 employees by a UK large Civil Service organization which has been previously criticized by the Government for being not enough innovative. This study is based on the use of specific thinking techniques (brainstorming, lateral thinking, mind-mapping, synthetics or morphological analysis) in order to improve the existing levels of creativity (Allen, 1962; Basadur, 1994; Buzan, 1995; De Bono, 1977, 1985; Gordon, 1961; Osborn, 1963; Parnes et al., 1977; Sternberg \& Lubart, 1999). The main characteristics of the business beyond the box programs are to give particular attention to radical goals setting and to strategies to achieve these goals inside the organization. The lateral thinking programs are more based on thinking technique as random association between concepts and to break problems in smaller components and to think about solutions for each component. De Bono programs, or six thinking hats, are more characterized by the use of six different modes of thoughts (informational, creative, logical positive, cautious, intuitive and processual).

The results of this study showed that beyond the box was the most successful workshop followed by six thinking hats and lateral thinking. De Bono workshop appeared to have a greater impact on knowledge improvement, while beyond the box produced changes in attitudes to innovation. The study showed also that the degree of management support and the departmental innovation climate have also a strong influence on the implementation of the ideas in the organization. These results are quite close to the literature about research which asserted that the work environment and climate can facilitate or inhibit the employees creative behavior in putting an innovative idea into practice (Oldham \& Cummings, 1996; Ekvall \& Ryhammar, 1999; Clegg et al., 2002).

\section{Conclusion and Final Remarks}

Based on some recent literature, we have identified in the present study four main areas of study on the topic of creativity and innovation. These areas are of course not to be considered as the definitive framework on this subject, but we hope that they can serve as guidelines to a better understanding of, the creative process that leads to the stabilization of the innovation. Organizational structures, individual characteristics, training methods and pedagogical practices and the training content can provide a specific map in which to understand and guide innovation processes in organizations.

Consider the example of technological innovation in education and training, which has led in recent years to the massive introduction of new technologies within school organizations (such as IWB, tablet, etc.). The innovation supported by new technologies refers to possible new ways of using and creating information and knowledge made possible by the use of ICT, instead of using ICT to support or replicate traditional instructional methods (Bocconi et al., 2012). It can occur both in formal and informal learning settings, from school age to adult education. Last but not least, this innovation should be implemented supporting pedagogical and institutional change.

About this massive introduction, today we do not know the real effects at the individual and group level (students and teachers) nor at the organizational level. What we do know is that the mere introduction of technology, if not supported, for example, by new teaching methods and classroom management procedures, new organizational structures (opening-up learning environments) may be essentially useless, and a waste in economic terms. Using the model proposed by Cooper (1998) on the innovation supported by new technologies, and a series of studies and experimentations in the Italian context (e.g. Gentile \& Pisanu, 2012; Gentile et al., 2013), it is possible to support the vision of "sustainable" in terms of incremental innovation, processes and technologies. The four areas identified in this review can be integrated, giving to each of the four dimensions an overview in terms of incremental innovation, processes and technologies. In this sustainable vision, educational and training innovation supported by new technologies should be based on the integration of old and new technologies, on a flexible use of learning environments already available, on an adaptation of instructional activities for the software already available and especially on innovation in educational practices. The social dimension (from the organizational and inter organizational point of view) needs to be considered also: creativity and innovation are not only related to the size of the brain, but also to the size of social groups and the connectivity of the groups (Pringle, 2013).

Social and macro-level issues are considered in the "Creative Classrooms” model (Bocconi et al., 2012). This is a multidimensional and holistic model for innovative learning environments that fully embed the potentials of ICT for learning. The model consists of eight encompassing and interconnected dimensions that capture the essential nature of these learning ecosystems: Content and Curricula, Assessment, Learning Practices, Teaching Practices, Organization, Leadership and Values, Connectedness, and Infrastructure. 


\section{Acknowledgements}

This project has been funded with support from the European Commission, support for the European Cooperation in Education and Training (ECET), Project number 521415-LLP-2011IT-KA1-KA1ECETB. We wish to thank all the CLEAR project partners: IPRASE (Trentino, Italy), Confindustria Veneto SIAV (Mestre, Italy), GuildHe (London, United Kingdom), EVTA The European Vocational Training Association (Brussels, Belgium), VEM Federación Vízcaína de Empresas del Metal (Bilbao, Spain), TKNIKA Centro de Innovación para la Formación Profesional (Errenteria, Gipuzkoa, Spain), BUC—Bergen University College-Hogskole i Bergen (Bergen, Norway). This publication reflects the views only of the author, and the Commission cannot be held responsible for any use which may be made of the information contained therein.

\section{REFERENCES}

Allen, M. (1962). Morphological creativity. Englewood Cliffs, NJ: Prentice-Hall.

Amabile, T. M. (1983). The social psychology of creativity. New York: Springer-Verlag. http://dx.doi.org/10.1007/978-1-4612-5533-8

Amabile, T. M. (1983). The social psychology of creativity: A componential conceptualization. Journal of Personality and Social Psichology, 45, 57-376. http://dx.doi.org/10.1037/0022-3514.45.2.357

Amabile, T. M. (1996). Creativity in context. Boulder, CO: West Piew Press.

Amabile, T. M. (1998). How to kill creativity. Harvard Business Review, September/October, 77-87.

Andrews, F. M., \& Farris, G. F. (1967). Supervisory practices and innovation on scientific teams. Personnel Psychology, 20, 497-515. http://dx.doi.org/10.1111/j.1744-6570.1967.tb02446.x

Antes, L. A., \& Schuelke, M. J. (2011). Leveraging technology to develop creative leadership capacity. Advances in Developing Human Resources, 13, 318-365. http://dx.doi.org/10.1177/1523422311424710

Antonites, A. J. (2003). An action learning approach to entrepreneurial creativity, innovation and opportunity finding. Ph.D. Thesis, Pretoria: Faculty of Economics and Management Science, University of Pretoria.

Ardichvili, A., Cardozo, R., \& Ray, S. (2003). A theory of entrepreneurial opportunity identification and development. Journal of Business Venturing, 18, 105-123.

http://sbaer.uca.edu/research/icbs/2003 http://dx.doi.org/10.1016/S0883-9026(01)00068-4

Bandura, A. (1977). Self-efficacy: Toward a unifying theory of behavioral change. Psychological Review, 84, 191-215.

http://dx.doi.org/10.1037/0033-295X.84.2.191

Barnowe, J. T. (1975). Leadership and performance outcomes in research organizations. Organizational Behavior and Human Performance, 14, 264-280.

http://dx.doi.org/10.1016/0030-5073(75)90029-X

Basadur, M. (1994). Managing the creative process in organizations. In M. Runco (Ed.), Problem finding, problem solving and creativity. Creativity research (pp. 237-268). Norwood, NJ: Ablex Publishing Corp.

Bereiter, C. (2002). Education and mind in the knowledge age. Mahwah, NJ: Lawrence Erlbaum.

Bils, M., \& Klenow, P. (2000). Does schooling cause growth? American Economic Review, 90, 328-335.

http://dx.doi.org/10.1257/aer.90.5.1160

Birdi, K. S. (2005). No idea? Evaluating the effectiveness of creativity training. Journal of European Industrial Training, 29, 102-111. http://dx.doi.org/10.1108/03090590510585073

Bocconi, S., Kampylis, P. G., \& Punie, Y. (2012). Innovating learning: Key elements for developing creative classrooms in Europe. Luxembourg: Publications Office of the European Union.
Boden, M. (1990). The creative mind: Myths and mechanisms. New York: Basic Books.

Boomer, G. (1992). Negotiating the curriculum: Educating for the 21st century. Washington DC: Falmer.

Bourner, T., \& Flowers, S. (1997). Teaching and learning methods in higher education: Glimpse of the future. Reflections on Higher Education, 9, 77-102.

Brundtland, G. (1987). Our common future: The world commission on environment and development. Oxford: Oxford University Press.

Buzan, T. (1995). The mindmap book. London: BBC Books.

Bygrave, W. (1994). The entrepreneurial process. In W. Bygrave (Ed.), The portable MBA in entrepreneurship. New York, NY: John Wiley.

Carey, C., \& Matlay, H. (2010). Creative disciplines education: A model for assessing ideas in entrepreneurship education? Education + Training, 52, 694-709.

Clegg, C. W., Unsworth, K. L, Epitropaki, O., \& Parker, G. (2002). Implicating trust in the innovation process. Journal of Occupational and Organizational Psychology, 75, 217-232. http://dx.doi.org/10.1348/096317902321119574

Companys, Y. E., \& McMullen, J. S. (2007). Strategic entrepreneurs at work: The nature, discovery, and exploitation of entrepreneurial opportunities. Small Business Economics, 28, 301-322. http://dx.doi.org/10.1007/s11187-006-9034-x

Cooper, J. R. (1998). A multidimensional approach to the adoption of innovation. Management Decision, 36, 493-502. http://dx.doi.org/10.1108/00251749810232565

Cope, J., \& Watts, G. (2000). Learning by doing: An exploration of experience, critical incidents and reflection in entrepreneurial learning. International Journal of Entrepreneurial Behaviour and Research, 6, 104-124. http://dx.doi.org/10.1108/13552550010346208

Cornish, L. (2007). Creative teaching: Effective learning in higher education. Paper Presented at 32nd International Conference on Improving University Teaching: The Creative Campus. 4-7 July, Jaen, Paper Retrieved from ProQuest Education Journals Database.

Csikszentmihalyi, M. (1988). Society, culture and person: A system view of creativity. In R. J. Sternberg (Ed.), The nature of creativity (pp. 325-329). New York: Cambridge University Press.

Cutler, T. (2003). Foreword to Australian edition of Richard Florida's (2002). The rise of the creative class. New York: Basic Books.

DCMS (2006). Definition of the creative industries. London: Department of Culture, Media and Sport. Creative Industries Division. www.culture.gov.uk/creative_industries

De Bono, E. (1977). Lateral thinking. Harmondsworth: Pelican.

De Bono, E. (1985). Six thinking hats. Harmondsworth: Viking.

Diehl, M., \& Stroebe, W. (1991). Productivity loss in idea-generating groups: Tracking down the blocking effect. Journal of Personality and Social Psychology, 61, 392-403.

http://dx.doi.org/10.1037/0022-3514.61.3.392

Doppelt, B. (2008). The power of sustainable thinking. London: Earthscan Publishing.

Eickhoff, M. T. (2008). Entrepreneurial thinking and action-An educational responsibility for Europe. European Journal of Vocational Training, 45, 5-31.

Ekvall, G., \& Ryhammar, L. (1999). The creative climate: Its determinants and effects at a Swedish university. Creativity Research Journal, 12, 303-310. http://dx.doi.org/10.1207/s15326934crj1204_8

Florida, R. (2002). The rise of the creative class. New York: Basic Books.

Florida, R. (2005). The flight of the creative class. New York: Collins.

Flynn, M., Doodley, L., \& Cormican, K. (2003). Idea management for organizational innovation. International Journal of Innovation Management, 7, 417. http://dx.doi.org/10.1142/S1363919603000878

Ford, C. M. (1996). A theory of individual creative action in multiple social domains. Academy of Management Review, 21, 1112-1142.

Garrison, D. R., Anderson, T., \& Archer, W. (2000). Critical inquiry in a text-based environment: Computer conferencing in higher education. The Internet and Higher Education, 2, 87-105. http://dx.doi.org/10.1016/S1096-7516(00)00016-6

Gentile, M., Pisanu, F., Gaetani, M. R., Filosi, G., \& Campregher, S. (2013). Tecnologie per insegnare e apprendere. Scuola Italiana Moderna, $120,59-62 / 86-88$. 
Gentile, M., \& Pisanu, F. (2012). Lavagne interattive multimediali, esperienza digitale percepita e conduzione della classe. Rapporto di ricerca del progetto RED 5. Trento: Editore Provincia Autonoma di Trento.

Gibb, A. A. (1985). Has entrepreneurship a place in the university? Durham: Durham University Business School.

Gibb, A. A. (1996). Entrepreneurship and small business management: Can we afford to neglect them in the twenty-first century business school? British Journal of Management, 7, 309-321. http://dx.doi.org/10.1111/j.1467-8551.1996.tb00121.x

Gibb, A. A. (1998). Educating tomorrow's entrepreneurs. Economic Reform Today, 4, 32-38.

Gibson, R. (2010). The 'art' of creative teaching: Implications for higher education. Teaching in Higher Education, 15, 607-613. http://dx.doi.org/10.1080/13562517.2010.493349

Gilbert, D. H. (2012). From chalk and talk to walking the walk: Facilitating dynamic learning contexts for entrepreneurship students in fasttracking innovations. Education + Training, 54, 152-166. http://dx.doi.org/10.1108/00400911211210260

Glaeser, E., La Porta, R., Lopez-De-Silanes, F., \& Schleifer, A. (2004). Do Institutions Cause Growth? NBER Working Paper No. 10568. Cambridge: National Bureau of Economic Research.

Gordon, W. (1961). Synectics. New York: Harper \& Row.

Grainger, T., Barnes, J., \& Scoffham, S. (2004). A creative cocktail: Creative teaching in initial teacher education. Journal of Education for Teaching: International Research and Pedagogy, 30, 243-253. http://dx.doi.org/10.1080/0260747042000309475

Granovetter, M. S., (1973). The strength of weak ties. American Journal of Sociology, 78, 1360-1380. http://dx.doi.org/10.1086/225469

Hamidi, D. Y., Wennberg, K., \& Bergland, H. (2008). Creativity in entrepreneurship education. Journal of Small Business and Enterprise Development, 15, 304-320. http://dx.doi.org/10.1108/14626000810871691

Hammedi, W., van Riel, A. C. R., \& Sasovova, Z. (2011). Antecedents and consequences of reflexivity in new product idea screening. Journal of Product Innovation Management, 28, 662-679.

Hannon, P. (2004). Making the Journey from Student to Entrepreneur: A Review of the Existing Research into Graduate Entrepreneurship. Birmingham: National Council for Graduate Entrepreneurship.

Haring-Smith, T. (2006). Creativity research review: Some lessons for higher education. Peer Review, 8, 23-30.

Heinonen, J., Hytti, U., \& Stenholm, P. (2010). Role of opportunity discovery strategies in business idea development in entrepreneurship research. Conference Proceedings of the 16th Nordic Conference on Small Business Research, Kolding, 20-21 May 2010. Kuopio: Kuopio University Press.

Heinonen, J., Hytti, U., \& Stenholm, P. (2011). The role of creativity in opportunity search and business idea creation. Education + Training, 53, 659-672. http://dx.doi.org/10.1108/00400911111185008

Hoegl, M., \& Gemuenden, H. G. (2001). Teamwork quality and the success of innovative projects: A theoretical concept and empirical evidence. Organization Science, 12, 435-449. http://dx.doi.org/10.1287/orsc.12.4.435.10635

Hoegl, M., \& Parboteeah, K. P. (2006). Team reflexivity in innovative projects. R\&D Management, 36, 113-125. http://dx.doi.org/10.1111/j.1467-9310.2006.00420.x

Hoegl, M., \& Parboteeah, K. P. (2007). Creativity in innovative projects: How teamwork matters. Journal of Engineering and Technology Management, 24, 148-166. http://dx.doi.org/10.1016/j.jengtecman.2007.01.008

Hunter, S. T., \& Cushenbery, L. (2011). Leading for innovation: Direct and indirect influences. Advances in Developing Human Resources, 13, 248-265. http://dx.doi.org/10.1177/1523422311424263

Kirzner, I. M. (1999). Creativity and/or alertness: A reconsideration of the Schumpeterian entrepreneur. The Review of Austrian Economics, 11, 5-17. http://dx.doi.org/10.1023/A:1007719905868

Koestler, A. (1964). The act of creation. New York: Macmillan.

Kuratko, D. F. \& Hodgetts, C. (1998). Entrepreneurship-A contemporary approach. Hinsdale, IL: The Dryden Press.

Madhavan, R., \& Grover, R. (1998). From embedded knowledge to em- bodied knowledge: New product development as knowledge management. Journal of Marketing, 62, 1-12. http://dx.doi.org/10.2307/1252283

Maslow, A. (1954). Motivation and personality. New York: Harper Row.

Matlay, H., \& Carey, C. (2006). Impact of entrepreneurial education on graduates in the UK: Conceptual and contextual implications. In EFMD 36th EISB Conference (Entrepreneurship, Innovation and Small Business Conference) Proceedings. Brussels: EFMD.

McEntire, L. E., \& Greene-Shortridge, T. M. (2011). Recruiting and selecting leaders for innovation: How to find the right leader. Advances in Developing Human Resources, 13, 266-278. http://dx.doi.org/10.1177/1523422311424712

Meadows, D., Randers, J., \& Meadows, D. (2004). Limits to growth: The 30 year update. Vermont: Chelsea Green Publishing.

Miller, D. (1987). The structural and environmental correlates of business strategy. Strategic Management Journal, 8, 55-76. http://dx.doi.org/10.1002/smj.4250080106

Mumford, M. D., \& Gibson, C. (2011). Developing leadership for creative efforts: A preface. Advances in Developing Human Resources, 13, 243-247. http://dx.doi.org/10.1177/1523422311425003

Mumford, M. D., Scott, G. M., Gaddis, B., \& Strange, J. M. (2002). Leading creative people: Orchestrating expertise and relationships. Leadership Quarterly, 13, 705-750. http://dx.doi.org/10.1016/S1048-9843(02)00158-3

OCSE/CERI (2010). The nature of learning: Using research to inspire practice. Paris: OECD Publishing.

Odoardi, C. (2008). L’innovazione nelle organizzazioni scolastiche: Una ricerca empirica. Risorsa Uomo: Rivista di Psicologia del Lavoro e dell'Organizzazione, 14, 71-84.

Okhuysen, G. A., \& Eisenhardt, K. M. (2002). Integrating knowledge in groups: How formal interventions enable flexibility. Organization Science, 13, 370-386. http://dx.doi.org/10.1287/orsc.13.4.370.2947

Oldham, G., \& Cummings, A. (1996). Employee creativity: Personal and contextual factors at work. Academy of Management Journal, 39, 607-634. http://dx.doi.org/10.2307/256657

Osborn, A. (1963). Applied imagination. New York: Charles Scribner's Sons.

Parnes, S., Noller, R., \& Biondi, A. (1977). Guide to creative action. New York: Charles Scribner's Sons.

Penaluna, A., \& Penaluna, K. (2009). Assessing creativity: Drawing from the experience of the UK's creative design educators. Education + Training, 51, 718-732.

http://dx.doi.org/10.1108/00400910911005262

Pittaway, L., \& Cope, J. (2007). Entrepreneurship education-A systematic review of the evidence. International Small Business Journal, 25, 477-506.

Pittaway, L., Hannon, P., Gibb, A., \& Thompson, J. (2009). Assessment practice in enterprise education. International Journal of Entrepreneurial Behaviour \& Research, 15, 71-93. http://dx.doi.org/10.1108/13552550910934468

Porter, M., Delgado, M., Ketels, C., \& Stern, S. (2008). Moving to a new global competitiveness index. In M. Porter, \& K. Schwab (Eds.), The global competitiveness report 2008-2009 (pp. 43-64). Geneva: World Economic Forum.

Porter, M., Schwab, K., Sala-I-Martin, X., \& Lopez-Claros, A. (2004). The global competitiveness report 2004-2005. New York: Oxford university Press.

Pringle, H. (2013). The origins of creativity. Scientific American, 308, 36-43. http://dx.doi.org/10.1038/scientificamerican0313-36

Puhakka, V. (2002). Entrepreneurial Business Opportunity Recognition. Relationships between Intellectual and Social Capital, Environmental Dynamism, Opportunity Recognition Behavior, and Performance. Ph.D. Thesis, Finland: University of Vaasa.

Puhakka, V. (2007). Effects of opportunity discovery strategies of entrepreneurs on performance of new ventures. Journal of Entrepreneurship, 16, 19-51. http://dx.doi.org/10.1177/097135570601600102

QAA (2008). Subject benchmark statement-Art and design. Gloucester: Quality Assurance Agency for Higher Education.

Rae, D. (2007). Entrepreneurship: From opportunity to action. New York: Palgrave Macmillan. 
Rae, D. (2010). Universities and enterprise education: Responding to the challenges of the new era. Journal of Small Business and Enterprise Development, 17, 591-606.

http://dx.doi.org/10.1108/14626001011088741

Rae, D., \& Carswell, M. (2000). Towards a conceptual understanding of entrepreneurial learning. The Journal of Small Business and Enterprise Development, 8, 150-158. http://dx.doi.org/10.1108/EUM0000000006816

Rees, M. (2003). Our final century. London: Heinemann.

Robinson, K. (2000). The creative enterprise: Investing in the arts in the 21st century. New stateman arts lecture. London: The Arts Council of England.

Ruscio, J., Whitney, D. M., \& Amabile, T. M. (1998). Looking inside the fishbowl of creativity: Verbal and behavioral predictors of creative performance. Creativity Research Journal, 11, 243-263. http://dx.doi.org/10.1207/s15326934crj1103_4

Sahlberg, P., \& Oldroyd, D. (2010). Pedagogy for economic competitiveness and sustainable development. European Journal of Education, Part I, 45, 280-299. http://dx.doi.org/10.1111/j.1465-3435.2010.01429.x

Salampasis, D. G. (2013). Enhancing creativity and innovation including entrepreneurship at all levels of education and training. The role of CLEAR Project. Brussels: ECET.

http://www.clearcreativity.eu/images-downloads/CLEAR-REPORT3 -en.pdf

Sarri, K. K., Bakouros, I. L., \& Petridou, E. (2010). Entrepreneur training for creativity and innovation. Journal of European Industrial Training, 34, 270-288. http://dx.doi.org/10.1108/03090591011031755

Sawyer, R. K. (2004). Creative teaching: Collaborative discussion as disciplined improvisation. Educational Researcher, 33, 12-20. http://dx.doi.org/10.3102/0013189X033002012

Sawyer, R. K. (2006). Educating for innovation. Thinking Skills and Creativity, 1, 41-48. http://dx.doi.org/10.1016/j.tsc.2005.08.001

Schulz-Hardt, S., Frey, D., Luthgens, C., \& Moscovici, S. (2000). Biased information search in group decision making. Journal of Personality and Social Psychology, 78, 655-669.

http://dx.doi.org/10.1037/0022-3514.78.4.655

Schumpeter, J. (1942). Capitalism, socialism and democracy. New York: Harper Torchbooks.

Sicotte, H., \& Langley, A. (2000). Integration mechanisms and R\&D project performance. Journal of Engineering and Technology Management, 17, 1-37.

http://dx.doi.org/10.1016/S0923-4748(99)00018-1

Simon, H., \& Hicks, J. (2006). Opening doors: Using the creative arts in learning and teaching. Arts and Humanities in Higher Education, 5, 77-90. http://dx.doi.org/10.1177/1474022206059998

Smith, A. J., Collins, L. A., \& Hannon, P. D. (2006). Embedding new entrepreneurship programmes in UK higher education institutions: Challenges and considerations. Education + Training, 48, 555-567. http://dx.doi.org/10.1108/00400910610710001

Smith, K., \& Beasley, M. (2011). Graduate entrepreneurs: Intentions, barriers and solutions. Education + Training, 53, 722-740. http://dx.doi.org/10.1108/00400911111185044

Solomon, G. (2005). Keystones of entrepreneurial knowledge. Malden, MA: Blackwell Publishing.

Steffen, W., Crutzen, P. J., \& Mcneill, J. R. (2007). The anthropocene: Are humans now overwhelming the great forces of nature? AMBIO, 36, 614-621.

http://dx.doi.org/10.1579/0044-7447(2007)36[614:TAAHNO]2.0.CO ;2

Sternberg, R. (2006). Introduction. In J. Kaufman, \& R. Sternberg (Eds.), The international handbook of creativity (pp. 1-9). Cambridge: Cambridge University Press.
Sternberg, R. J., \& Lubart, T. I. (1999). The concept of creativity: Prospects and paradigms. In R. J. Sternberg (Ed.), Handbook of creativity (pp. 3-16). New York: Cambridge University Press.

Schwartz, D. L., Varma, S., \& Martin, L. (2008). Dynamic transfer and innovation. In S. Vosniadou (Ed.), International handbook of research on conceptual change (pp. 479-506). New York: Routledge.

Taggar, S. (2002). Individual creativity and group ability to utilize individual creative resources: A multilevel model. Academy of Management Journal, 45, 315-330. http://dx.doi.org/10.2307/3069349

Tang, J., \& Khan, S. A. (2007). Dynamic interactions between alertness and systematic search: A yin and yang perspective on opportunity recognition and innovation. International Journal of Entrepreneurship and Innovation, 8, 175-187. http://dx.doi.org/10.5367/000000007781698518

Tannenbaum, S. I., Beard, R. L., \& Salas, E. (1992). Team building and its influence on team effectiveness: An examination of conceptual and empirical developments. In K. Kelley (Ed.), Issues, theory, and research in industrial/organizational psychology (pp. 117-153). Amsterdam: Elsevier. http://dx.doi.org/10.1016/S0166-4115(08)62601-1

Thompson, L. (2003). Improving the creativity of organizational work groups. Academy of Management Executive, 17, 96-109. http://dx.doi.org/10.5465/AME.2003.9474814

TRACTORS project (2007). Training material in creativity and innovation for European R\&D Organizations and SMEs. Pr. No. ES/ 06/B/F/PP-149462. The Leonardo da Vinci Program.

http://www.train4creativity.eu/dat/DD4AA487/file.pdf?6347113391 10880000

Unesco (2005). United Nations decade of education for sustainable development 2005-2014. International Implementation Scheme. (ED/DESD/2005/PI/01). Paris: UNESCO.

Van Vuuren, J. J. (1997). Entrepreneurship education and training: A prospective content model. Unpublished Paper.

Vesper, K. H., \& McMullan, W. E. (1988). Entrepreneurship: Today courses, tomorrow degrees? Entrepreneurship, Theory and Practice, 13, 7-13.

Vinarski-Peretz, H., \& Carmeli, A. (2011). Linking care felt to engagement in innovative behaviors in the workplace: The mediating role of psychological conditions. Psychology of Aesthetics, Creativity, and the Arts, 5, 43-53. http://dx.doi.org/10.1037/a0018241

Wakeford, C. (2011). Evolution of E-learning Projects: A creative experience? Bioscience Education, 18. www.bioscience.heacademy.ac.uk/journal/vol18/beej-18-1SE.pdf

Watson, W., Michaelsen, L. K., \& Sharp, W. (1991). Member competence, group interaction, and group decision making: A longitudinal study. Journal of Applied Psychology, 76, 803-809. http://dx.doi.org/10.1037/0021-9010.76.6.803

Weick, K. E. (1995). Sensemaking in organizations. Thousand Oaks, CA: SAGE.

Weick, K. E., \& Roberts, K. H. (1993). Collective mind in organizations: Heedful interrelating on flight decks. Administrative Science Quaterly, 38, 357-381. http://dx.doi.org/10.2307/2393372

West, M. A. (2000). Reflexivity, revolution, and innovation in work teams. In M. M. Beyerlein, D. A. Johnson, \& S. T. Beyerlein (Eds.), Product development teams (pp. 1-29). Stanford, CT: JAI Press.

West, M. A., \& Farr, J. L. (1990). Innovation at work. In M. A. West, \& J. L. Farr (Eds.), Innovation and creativity at work: Psychological and organizational strategies (pp. 3-13). Chichester: Wiley.

West, M. A., \& Rickards, T. (1999). Innovation. In M. A. Runco, \& S. R. Prentky (Eds.), Encyclopedia of creativity (pp. 45-55). San Diego: Academic Press.

Zhao, F. (2005). Exploring the synergy between entrepreneurship and innovation. International Journal of Entrepreneurial Behaviour and Research, 11, 25-41. http://dx.doi.org/10.1108/13552550510580825 